\title{
Staple Device
}

National Cancer Institute

\section{Source}

National Cancer Institute. Staple Device. NCI Thesaurus. Code C50307.

A fastening device consisting of a bent wire designed to pierce and hold. 